\title{
Evaluation of recurrence of musculoskeletal tumors with thallium-201 scintigraphy plus SPECT/CT in a pediatric population
}

\author{
Sevastián S. Medina-Ornelas ${ }^{*}$, Herlinda Vera-Hermosillo², Rafael Delgado-Espín ${ }^{2}$ and \\ Francisco O. García-Pérez ${ }^{1}$
}

${ }^{1}$ Departamento de Medicina Nuclear e Imagen Molecular, Instituto Nacional de Cancerología; ${ }^{2}$ Departamento de Medicina Nuclear, Hospital Infantil de México Federico Gómez. Mexico City, Mexico

\begin{abstract}
Background: Imaging studies, particularly simple and contrast-enhanced tomography, constitute the first diagnostic approach to detect recurrence of musculoskeletal tumors. The present retrospective study aimed to demonstrate the utility of scintigraphy plus SPECT/CT (single photon emission computed tomography) with thallium-201 (201 TI) in the evaluation of malignant musculoskeletal tumors with suspicion of recurrence or metastatic disease. Methods: Eight weeks after the last therapy, 72 scintigraphy and SPECT/CT studies were performed to assess regional recurrence and metastatic disease in 42 patients with different types of malignant musculoskeletal tumors, such as osteosarcoma, Ewing's sarcoma, rhabdomyosarcoma, retinoblastoma, synovial sarcoma, and Wilms tumor at the Hospital Infantil de México Federico Gómez. The positive predictive value (PPV) and the confidence interval of the scintigraphy and SPECT/CT were calculated when compared with the results of the histopathological analysis and the clinical and radiological follow-up for the identification of recurrence. Results: Scintigraphy was abnormal in 30 (71.4\%) of the 42 patients; 33 lesions (30 patients) were detected by scintigraphy and 25 lesions (21 patients) by chest X-ray and tomography of two regions. The SPECT/CT was performed on 30 patients, where 12 lesions were detected in addition to the planar scintigraphy. Scintigraphy showed a PPV of $82 \% ;$ SPECT/CT, $100 \%$. Conclusion: ${ }^{201} \mathrm{TI}$-scintigraphy can be considered as an adequate study to identify the sites of tumor viability with a high degree of diagnostic certainty combined with the SPECT/CT technique.
\end{abstract}

Key words: Scintigraphy. SPECT/CT. Thallium-201. Musculoskeletal tumors.

\section{Evaluación de la recurrencia de tumores musculoesqueléticos mediante gammagrafía complementada con SPECT/CT con talio-201 en población pediátrica}

\section{Resumen}

Introducción: Los estudios de imagen, como la tomografía simple y contrastada, son la primera aproximación diagnóstica para detectar la recurrencia de tumores musculoesqueléticos. El objetivo de este estudio retrospectivo fue demostrar la

Correspondence:

*Sevastián S. Medina Ornelas

Email: dr.sevastian@outlook.com

DOI: 10.24875/BMHIME.M18000022
Available online: 12-07-2018 Bol Med Hosp Infant Mex. 2018;75:29-37 www.bmhim.com

2444-3409/@ 2018. Hospital Infantil de México Federico Gómez, published by Permanyer México SA de CV, all rights reserved. 
utilidad de la gammagrafía acoplada a SPECT/CT con talio-201 (201 TI) en la valoración de tumores musculoesqueléticos malignos con sospecha de recurrencia o enfermedad metastásica. Métodos: Se realizaron 72 estudios gammagráficos y SPECT/CT para la valoración de recurrencia locorregional y a distancia, al menos 8 semanas posteriores a la última terapia, en 42 pacientes con diferentes tipos de tumores musculoesqueléticos malignos como osteosarcoma, sarcoma de Ewing, rabdomiosarcoma, retinoblastoma, sarcoma sinovial y tumor de Wilms en el Hospital Infantil de México. Se calculó el valor predictivo positivo (VPP) y el intervalo de confianza del gammagrama y del SPECT/CT comparado con el resultado del análisis histopatológico y el seguimiento clínico y radiológico para identificar recurrencia. Resultados: La gammagrafía fue anormal en 30 (71.4\%) de los 42 pacientes. Se detectaron 33 lesiones (30 pacientes) por gammagrafía y 25 (21 pacientes) por telerradiografía de tórax y tomografía de dos regiones. EI SPECT/CT se realizó en 30 pacientes y se detectaron 12 lesiones adicionales al rastreo planar. EI VPP con gammagrafía fue del $82 \%$, y con SPECT/CT, del 100\%. Conclusión: La gammagrafía con ${ }^{201} \mathrm{TI}$ puede considerarse como un estudio adecuado para identificar los sitios de viabilidad tumoral, con alto grado de certeza diagnóstica al complementar con SPECT/CT.

Palabras clave: Gammagrafía. SPECT/CT. Talio-201. Tumores musculoesqueléticos.

\section{Introduction}

The diagnosis of recurrence in musculoskeletal tumors can be a problem in the absence of specific markers. In most cases, simple and contrast tomography of one or two regions is the first diagnostic approach, although it highlights the high rate of false negatives in the locoregional recurrence scenario., ${ }^{1,2}$

The ${ }^{201} \mathrm{Tl}$ is a radioisotope that, unlike technetium- $99 \mathrm{~m}$ $\left({ }^{99 \mathrm{mTC}}\right)$, is produced in the cyclotron and has a greater physical half-life of 73.5 hours. Mercury-201 is disintegrated by electronic capture, with the emission of gamma rays of $137 \mathrm{keV}$ and $167 \mathrm{keV}$ (only $10 \%$ of abundance) and the rest of 69-83 keV (mercurial X-rays). ${ }^{3,4}$

For decades, thallium chloride-201 $\left({ }^{201} \mathrm{TI}\right)$ has been an agent widely used in nuclear medicine for the characterization of tumors, as well as in the evaluation of its response and recurrence. However, due to the introduction of the Positron Emission Tomography-Computed Tomography (PET/CT), it has been abandoned in many nuclear medicine centers. ${ }^{5-7}$

On the other hand, the availability and cost of PET/ CT studies have limited the physician to the performance of screening studies, with the loss of useful information provided by the scintigraphic and hybrid SPECT/ CT (single photon emission computed tomography) image with ${ }^{201} \mathrm{Tl}$.

Scintigraphy is an imaging technique used by nuclear medicine that involves the administration of a radionuclide that accumulates in the organ or tissue being studied, followed by the recording of the distribution of radioactivity using a gamma camera. When a full-body scan is performed, that concept can be synonymous with a whole-body planar scan in the specified projections. SPECT is an imaging modality that some gamma cameras have in which it is possible to visualize the organ or area of interest, obtaining three-dimensional images through the emission of the gamma rays of the radionuclide administered. When some gamma cameras include tomographic equipment, they are called hybrid equipment, that is, SPECT/CT. The scintigraphic findings are anatomically correlated..$^{7-9}$

The pharmacokinetic properties of ${ }^{201} \mathrm{TI}$ are very similar to potassium, allowing the localization method in tumors to be mainly due to blood flow and the presence of the $\mathrm{Na}^{+} / \mathrm{K}^{+} A T P$ ase pump. However, other theories indicate that various factors are involved in the uptake and retention of this agent, such as tumor viability, the exchange of calcium channels, the permeability of the cell membrane and even the tumor type. After its intravenous administration, ${ }^{201} \mathrm{~Tb}$ is released into the tumor via the bloodstream and is rapidly captured by viable cells during the high extraction of the first step, because the uptake is mediated mainly by the $\mathrm{Na}^{+} / \mathrm{K}^{+} A T P a s e$ pump that is found as a substrate of the tumor cells (uptake mechanism in solid tumors). ${ }^{6-8}$

The uptake of ${ }^{201} \mathrm{TI}$ is not exclusive of malignant lesions. Also, the bone and soft tissue lesions can capture this inflammatory radioisotope, as well as some benign tumors, like fibrous dysplasia or in Paget's disease $^{9,10}$ For this reason, it is essential to make the correct differentiation and correlation with an anatomical method such as with an integrated tomography in a hybrid equipment, to reduce the impact of false positives and improve the specificity of some abnormal uptake in an oncological context of metastatic disease.

This study aimed to define the usefulness of scintigraphy and SPECT/CT with ${ }^{201} \mathrm{TI}$ in the evaluation of malignant musculoskeletal tumors with clinical suspicion of recurrence or metastatic diseases. 


\section{Methods}

A retrospective study was conducted in which 42 patients with different types of malignant musculoskeletal tumors such as osteosarcoma, Ewing's sarcoma, rhabdomyosarcoma, retinoblastoma, synovial sarcoma and Wilms' tumor were studied between January 2015 and October 2016 in the Hospital Infantil de México Federico Gómez (HIMFG). Of the 42 patients, 26 were male, with an age range of 2-16 years and an average of 7.8 years old (48\%). Pathology confirmed initial diagnoses of malignancy in all the patients (Table 1).

The studies (42 scintigraphic and 30 SPECT/CT) were performed for the assessment of recurrence due to clinical suspicion and inconclusive results of the computed tomography and chest teleradiography, at least eight weeks (median 25.3 weeks, confidence interval (Cl) 95\%) after the last therapy (Table 2). The results of the studies with ${ }^{201} \mathrm{TI}$ were compared with the clinical follow-up in 28 patients and with the histopathological findings in 14 patients, at least four weeks after the studies with ${ }^{201} \mathrm{TI}$.

Based on histopathological findings and after clinical follow-up confirmed recurrence, they cases were considered true positives. The patients, who presented negative studies with ${ }^{201} \mathrm{TI}$ without clinical evidence of recurrence and with negative pathological findings, were considered as true negatives.

The informed consent was obtained from the parents of all the patients after having been explained the procedure in detail.

Full-body planar scans were acquired in anterior and posterior projection 10-15 minutes after the average intravenous administration of $74 \mathrm{MBq}(2 \mathrm{mCi})$ of ${ }^{201} \mathrm{TI}$ chloride. The dose was estimated based on the weight of the patient: a dose of $0.03-0.05 \mathrm{mCi} / \mathrm{kg}$ (1.11-1.85 MBq/kg), a minimum dose of $0.5 \mathrm{mCi}(18.5$ $\mathrm{mBq})$ and maximum of $2 \mathrm{mCi}(74 \mathrm{MBq})$.

The screening was performed with the Symbia system by SIEMENS $₫$ equipped with low-energy, high-resolution collimators, with a matrix of $128 \times 128$ at a speed of $8 \mathrm{~cm} / \mathrm{min}$. The parameters of low dose computed tomography (CT) included $130 \mathrm{kVp}$ and $100 \mathrm{mAs}$; the images were reconstructed with a section thickness of $5 \mathrm{~mm}$ in a $256 \times 256$ matrix. For this activity in $\mathrm{MBq}$, the dose of radiation absorbed by the target organ (myocardium) is approximately 15 mGy and the typical radiation doses absorbed by critical organs (kidneys and descending colon) are $35 \mathrm{mGy}$ and $23 \mathrm{mGy}$ respectively.
Table 1. Characteristics of the studied population

\begin{tabular}{|l|c|c|}
\hline Characteristics & $\mathbf{n}$ & Mean (\%) \\
\hline Age (years) & & $7.8(48 \%)$ \\
\hline Sex & & \\
$\quad$ Male & 26 & $61.9 \%$ \\
$\quad$ Female & 16 & $38.1 \%$ \\
\hline Histopathology & & \\
Osteosarcoma & 18 & $42.8 \%$ \\
Ewing's sarcoma & 12 & $28.5 \%$ \\
Rhabdomyosarcoma & 7 & $16.6 \%$ \\
Retinoblastoma & 2 & $4.8 \%$ \\
Synovial sarcoma & 2 & $4.8 \%$ \\
Wilms tumor & 1 & $2.4 \%$ \\
\hline
\end{tabular}

Pathology confirmed diagnoses of malignancy in all patients

The SPECT/CT of the areas of interest was obtained after the acquisition of the planar screening with the same equipment. The acquisition parameters of the SPECT comprised energy window counts of $15 \%$ at 140 $\mathrm{keV}$, acquired in a $128 \times 128$ matrix, resulting in a pixel size of $4.6 \times 4.6 \mathrm{~mm}$. 64 frames were obtained (30 seconds per frame) in a $360^{\circ}$ orbit. The heads of the cameras were configured with low energy and high-resolution collimators. The reconstruction was performed using Iterative Three-dimensional Ordered-Subset Expectation-Maximization with four iterations and eight subsets. Images were smoothed using three-dimensional Gaussian kernels with $10 \mathrm{~mm}$ full-width at half maxima (FWHM).

The images were evaluated by two nuclear physicians, who defined as abnormal study those scans with increased uptake, focal or diffuse, in comparison with the organs of the normal biodistribution of the radioisotope, and as a negative study, that without abnormal uptake (Fig. 1).

Studies with morphological abnormalities associated with ${ }^{201} \mathrm{TI}$ uptake were assessed as positive for recurrence. The positive predictive value (PPV) and the $\mathrm{Cl}$ of the scintigraphy and SPECT/CT were estimated and compared with the results of the histopathological analysis, the clinical assessment and the radiological follow-up for the recurrence confirmation. False negatives were also assessed.

\section{Results}

Of the 42 patients, 18 were diagnosed with osteosarcoma, 12 with Ewing sarcoma, seven with rhabdomyosarcoma, two with retinoblastoma, two with synovial sarcoma and one with a Wilms tumor. 
Table 2. Last treatment of the studied population

\begin{tabular}{|l|c|c|c|c|c|l|}
\hline Patients & Surgery & CT & RT & CT/T & Trimoda** $^{\text {Period }}$ \\
\hline 42 & 11 & 16 & 5 & 7 & 3 & Medium 25.3 weeks $95 \%$ Cl (8.2-44.6 weeks) \\
\hline
\end{tabular}

$\mathrm{CT}$, chemotherapy; $\mathrm{RT}$, radiotherapy; $\mathrm{Cl}$, confidence interval.

*With three types of treatment used: surgery + CT + RT because of the clinical suspicion and inconclusive results from the computed tomography and chest teleradiography 8.2-44.6 weeks after last treatment.

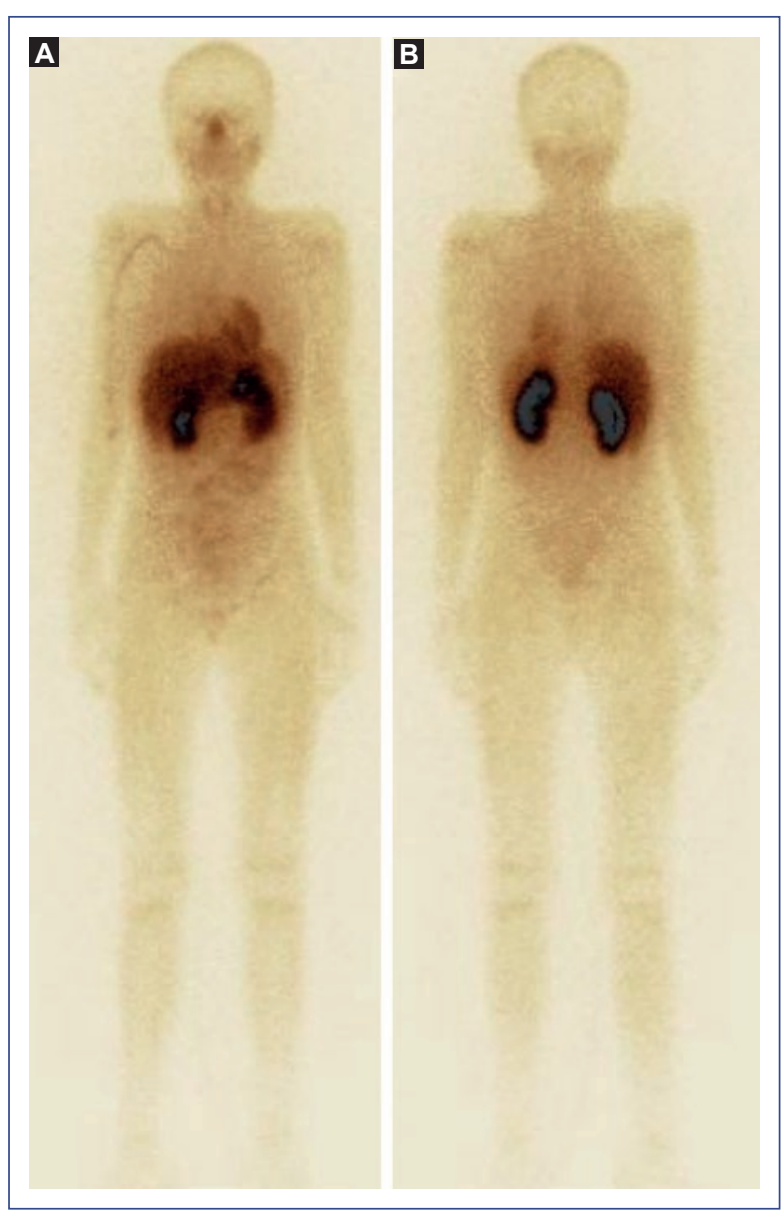

Figure 1. Planar whole-body scanning in anterior $(\mathbf{A})$ and posterior projection (B) with ${ }^{201} \mathrm{TI}$, where the normal biodistribution and elimination pathways are observed.

Planar screening with ${ }^{201} \mathrm{TI}$ chloride was abnormal in $30(71.4 \%)$ of the 42 patients, at least eight weeks (median 25.3 weeks, $95 \% \mathrm{Cl}$, 8.2-44.6 weeks) after therapy (Table 2). The indication for assessing locoregional and distant tumor (recurrence) viability was complemented by the SPECT/CT technique of the positive tracking area (Figs. 2 and 3). With the SPECT/CT, three sites of unsuspected metastasis were found in three patients: one in the breast (Fig. 4), one in the contralateral bone and one in the ipsilateral bone, not detected by other imaging methods (chest teleradiography and computed tomography). These sites were supported by the pathology department of the HIMFG, achieving a change in the management of these patients.

With the whole-body planar screening 33 sites were detected (in 30 patients), and with other imaging methods (chest teleradiography and computed tomography), 30 sites were detected (in 21 patients). The SPECT/CT performed to the 30 patients with positive findings in the planar scan detected 45 sites (Table 3), including small lesions at the pulmonary and axillary level (in those patients with lung lesions $>11 \mathrm{~mm}$ who required SPECT/CT for abnormal uptake in pulmonary topography evaluated in the scintigraphy and two axillary adenopathies of $10 \mathrm{~mm}$ ).

Three of the 30 patients with positive findings in the planar scan were determined as false positives when supplementing with SPECT/CT, due to surface contamination of the patient. Of the 27 patients with positive findings, 14 were confirmed by pathology and 13 by follow-up. No false positives were found with SPECT/CT.

Recurrence was confirmed by histopathology in 14 cases with medium and long-term clinical and radiological follow-up of 13 patients, with a mean follow-up time of $8.3 \pm 5.9$ months.

Six patients $(14.2 \%)$ of the 12 with negative screening (28.6\%) were determined as false negatives due to the inability to detect at the liver level in the planar screening by tumor size $(<10 \mathrm{~mm})$. These findings were confirmed with a liver MRI. In the remaining six patients, no recurrence was documented in the follow-up period (8.3 \pm 5.9 months, $95 \% \mathrm{Cl} 3.2-15.6$ months).

Fourteen patients had surgical treatment and chemotherapy; seven patients only received surgical treatment; seven only were treated with chemotherapy; the remaining two were sent to palliative care.

The PPV of the scintigraphic study was $82 \%$ (Table 4) while the PPV of the SPECT/CT study was $100 \%$ (Table 5), although no biopsy was taken in all patients because some recurrences were at the pulmonary level. In this way, the hybrid technique to abnormal findings stands out. 


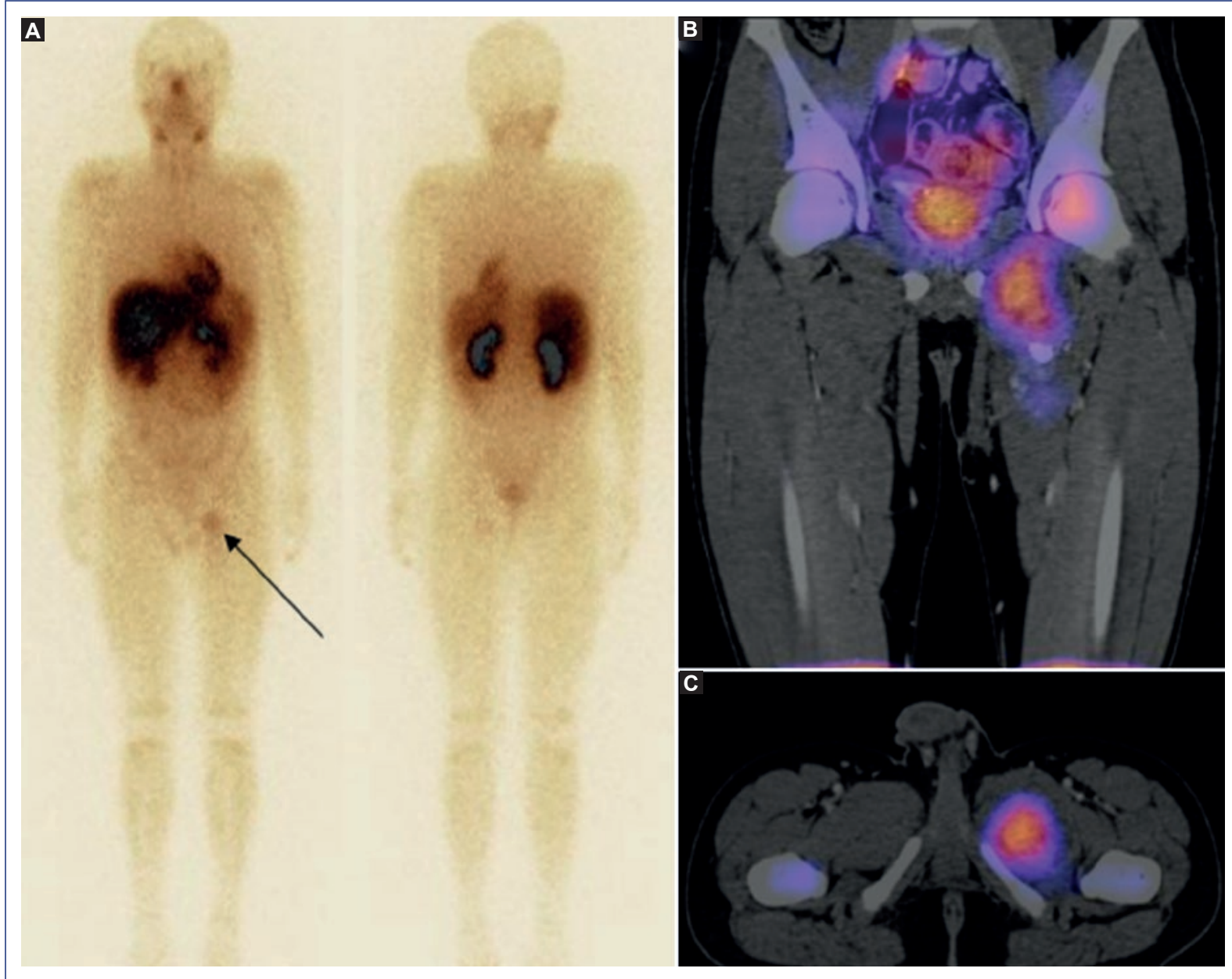

Figure 2. A: Planar whole-body scanning in anterior and posterior projection with ${ }^{201} \mathrm{TI}$, where normal biodistribution plus an abnormal focal increase in the uptake on the inner side of the left thigh is observed (arrow). It was complemented with a SPECT/CT in coronal (B) and axial (C) projections, where a hypodense lesion at the level of the muscle associated with the uptake of the radionuclide is observed in a patient diagnosed with rhabdomyosarcoma after four cycles of chemotherapy. The study was compatible with tumor viability at this level.

Table 3. Findings of the study with ${ }^{201} \mathrm{Tl}$ according to the histopathological type

\begin{tabular}{|c|c|c|c|c|c|}
\hline \multirow[t]{3}{*}{ Diagnosis } & \multirow[t]{3}{*}{ Patients (n) } & \multicolumn{4}{|c|}{ Collection ${ }^{201} \mathrm{TI}$} \\
\hline & & \multicolumn{2}{|c|}{ Scintigraphy } & \multicolumn{2}{|c|}{ SPECT/CT * } \\
\hline & & Positive & Negative & Positive & Negative \\
\hline Osteosarcoma & 18 & 14 & 4 & 13 & 10 \\
\hline Ewing's sarcoma & 12 & 8 & 4 & 7 & $1 \frac{0}{3}$ \\
\hline Rhabdomyosarcoma & 7 & 4 & 3 & 3 & $1 \frac{n}{c}$ \\
\hline Retinoblastoma & 2 & 1 & 1 & 1 & -4 \\
\hline Synovial sarcoma & 2 & 2 & - & 2 & $\frac{\pi}{2}$ \\
\hline Wilms tumor & 1 & 1 & - & 1 & $-\frac{0}{z}$ \\
\hline
\end{tabular}

The three patients with positive findings in the planar scan were false positives when supplemented with the SPECT/CT technique (patient surface contamination). ${ }^{*}$ SPECT/CT, single photon emission computed tomography; ${ }^{201 T I}$, thallium-201. 


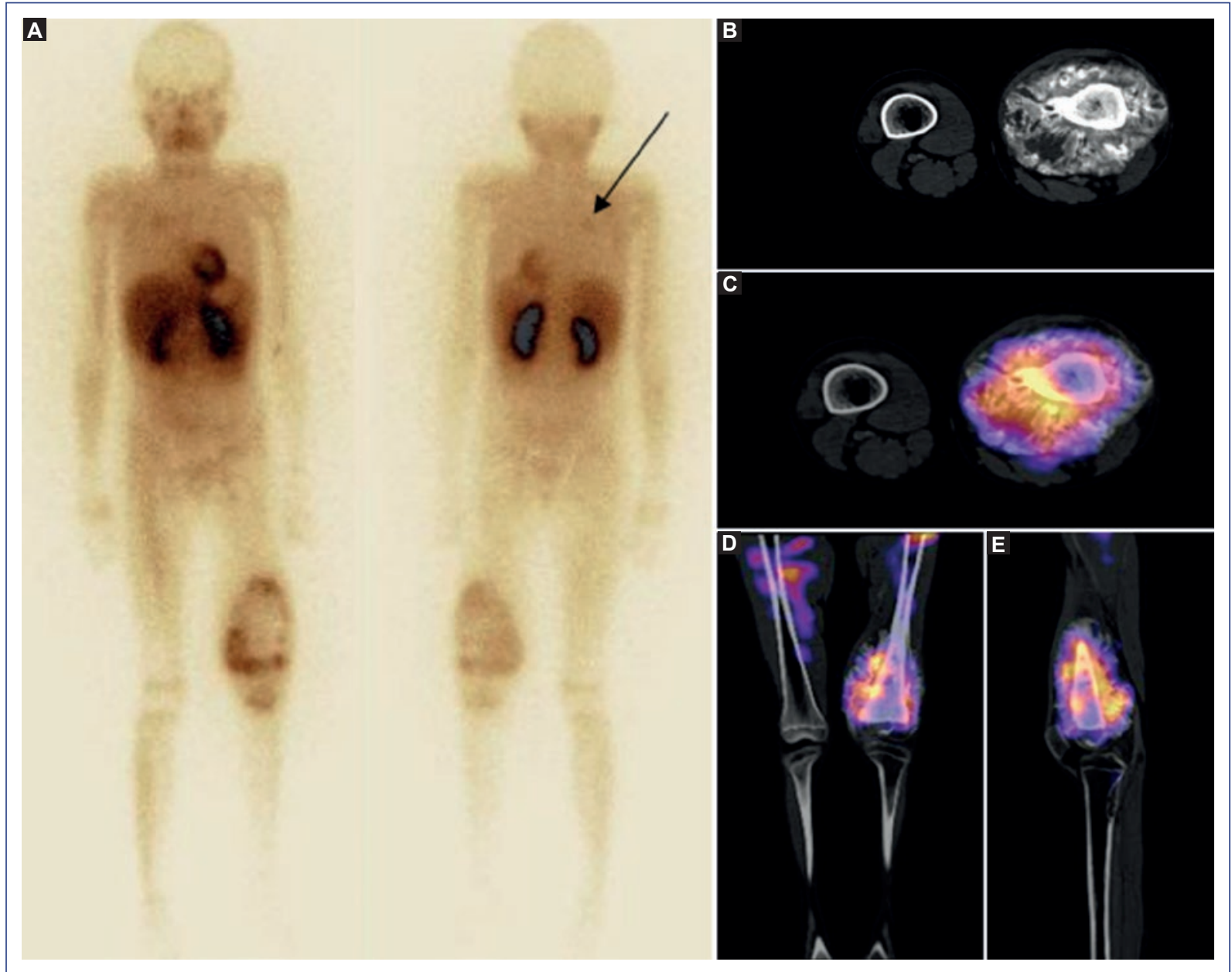

Figure 3. A: Whole-body scanning in anterior and posterior projection with ${ }^{201} \mathrm{Tl}$, where the normal biodistribution is observed, in addition to the abnormal focal increase of the uptake in the distal third of the left thigh and a focal zone towards the right parasternal middle line (arrow). It was complemented with SPECT/CT of the pelvic limbs, observing bone tumor in the distal third of the left femur, which erodes the cortex in the non-merged study (B). It was associated with an important uptake of radionuclide (C,D,E) when fused with SPECT. SPECT/CT confirmed lung injury.

Table 4. Results of patients with clinical suspicion of recurrence assessed with g-type

\begin{tabular}{|l|c|c|}
\hline \multicolumn{3}{|c|}{ Final diagnosis $(\mathbf{n}=\mathbf{4 2})$} \\
\hline & Recurrence $(+)$ & Recurrence (-) \\
\hline Scintigraphy & & \\
Positive & 27 & 3 \\
Negative & 6 & 6
\end{tabular}

Positive predictive value of $82 \%$.

During follow-up, some patients had changes in their therapeutic strategy. For this reason, follow-up was considered part of the standard in those patients in whom it was not possible to perform a biopsy. In the remaining
Table 5. Results of patients with clinical suspicion of recurrence abnormal scintigraphic findings evaluated with SPECT/CT ( $n=30$, when the complement was used because of abnormal scintigraphic findings)

\begin{tabular}{|c|c|c|c|}
\hline \multicolumn{3}{|c|}{ Final diagnosis } \\
\hline & Recurrence (+) & Recurrence (-) \\
\hline SPECT/CT & & & \\
Positive & 27 & 0 & $\varrho$ \\
Negative & 0 & 3 & $\cdots$ \\
\hline
\end{tabular}

*SPECT/CT, single photon emission computed tomography; ${ }^{201} \mathrm{Tl}$, thallium-201. Positive predictive value of $100 \%$.

patients, biopsies were performed which were positive in those patients with positive findings with SPECT/CT. 


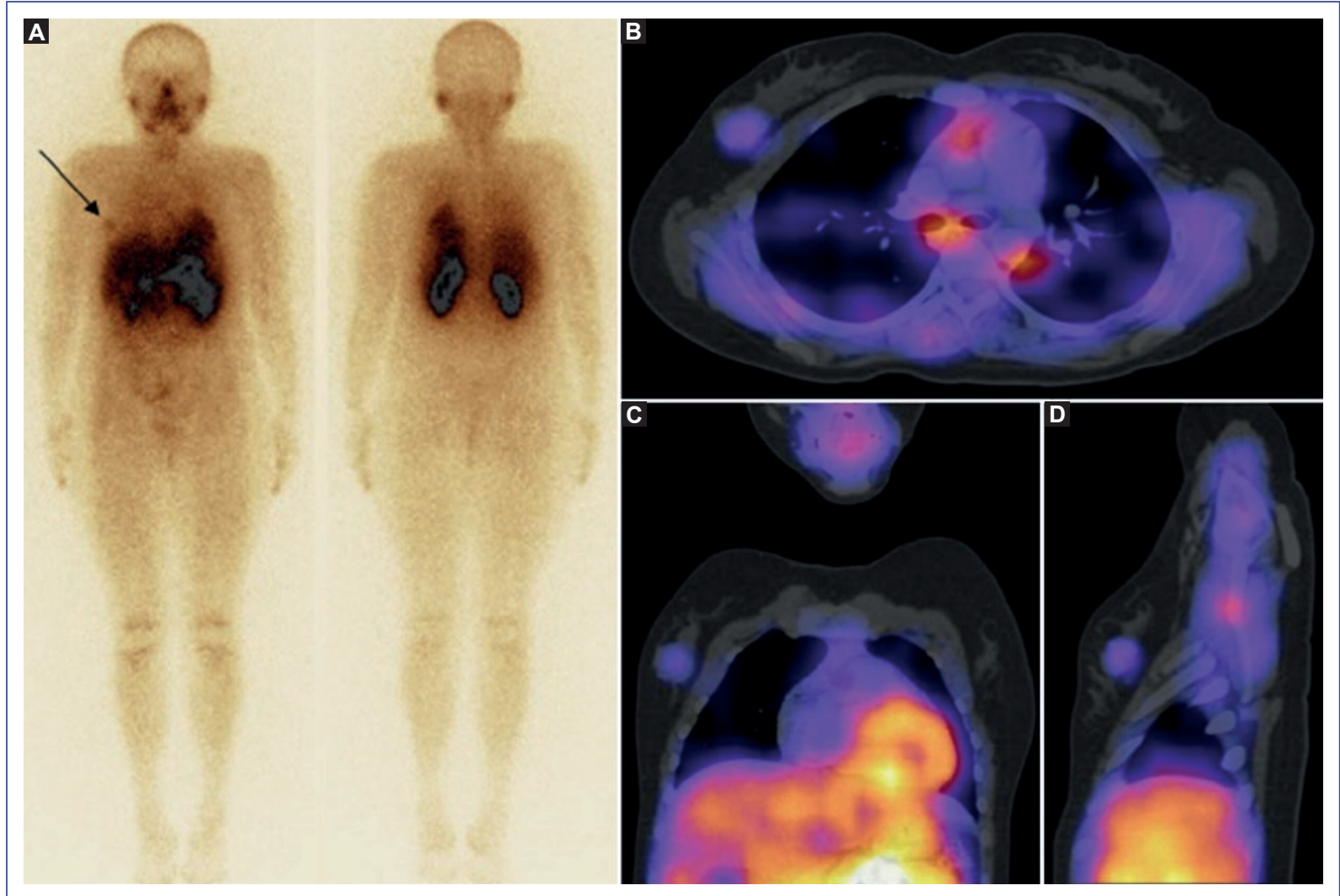

Figure 4. A: Whole-body scanning in anterior and posterior projection with ${ }^{201} \mathrm{Tl}$, where the normal biodistribution is observed, in addition to the abnormal focal increase of the uptake in thoracic right lateral topography (arrow). It was complemented with SPECT/CT, observing in the axial image (B) a hyperdense, rounded tumor, towards the upper external quadrant of the right breast, approximately $12 \mathrm{~mm}$ in diameter, associated with the uptake of the radionuclide, which is corroborated with the coronal (C) and sagittal (D). The study was compatible with recurrence in the right breast.

\section{Discussion}

The present study provides the greatest clinical significance in the evaluation of the extent of malignant musculoskeletal tumors, with VPP for scintigraphy of $82 \%$ and SPECT/CT of $100 \%$. Due to the sequence of the studies, an impact on the change in oncological management was shown in five patients $(11.9 \%)$.

The acquisition of early images (10-20 min post-injection) reflects the perfusion and tumor viability, while the late images reflect the kinetics of cellular uptake primarily. However, the validation of late images in tumors, due to the kinetics involved in washing, requires studies that indicate its usefulness and reproducibility.

The results observed differ concerning reports published in the international literature. In an evaluation of 37 patients with soft tissue sarcomas, Değirmenci et al. found a sensitivity and specificity of $68 \%$ and $87 \%$, respectively, in the recurrence detection. ${ }^{11}$

In a similar study, Caluser et al. demonstrated that ${ }^{201} \mathrm{TI}$ persistent uptake in late screenings, highlighting a VPP of $100 \%$, and negative predictive value of $37 \% .^{12}$
Bone tumors and some sarcomas are characterized by having an aggressive course and being highly vascularized, which allows ${ }^{201} \mathrm{TI}$ to have good sensitivity in the detection of lesions greater than $11 \mathrm{~mm}$ and, because of the uptake characteristics in the malignant tissue of this radionuclide, has a specificity close to $100 \%$, which allows optimal oncological management if performed on time. ${ }^{13,14}$

The impact of ${ }^{201} \mathrm{Tl}$ imaging in this type of neoplasms is related to the detection capacity of tumors not completely clarified by anatomical imaging methods.

Whole-body scintigraphy with ${ }^{201} \mathrm{TI}$ provides information about the unsuspected metastatic disease. However, the most common site of metastasis in these entities are the lungs and, unless the secondary deposits are larger than $11 \mathrm{~mm}$, they are unlikely to be detected by whole-body scintigraphy alone. The hybrid thoracic imaging technique should not be performed routinely in patients who do not present abnormal findings in the whole body scan; in these cases, anatomical imaging 
methods are the study of choice..$^{15}$ For this reason, it is important to note that, based on this methodology and observed results, only the abnormal scintigraphic findings were supplemented with the hybrid technique (SPECT/CT), with the aim of decreasing the additional CT radiation. Due to the small size of the lesions $(<11 \mathrm{~mm})$, these were not detected by the scintigraphic method without the SPECT/CT complement. With the present study, a $7 \%$ false negative rate was documented due to superficial contamination, as well as 15 additional lesions not visualized in the scintigraphic study. Given the above, regardless of the scintigraphic findings, if the study with ${ }^{201} \mathrm{TI}$ is requested in advance during the study sequence, and the suspicion is high, the advantages of the hybrid equipment can be used of to carry out a comprehensive assessment and therefore avoid carrying out separate tomographic studies, decreasing the radiation exposure and the time spent in hospital.

Sugawara et al. research the rate of elimination ("washout") of ${ }^{201} \mathrm{TI}$ in malignant lesions, finding markedly higher retention in malignant tumors concerning benign lesions, with a high negative predictive value greater than $90 \% .{ }^{16}$ However, although the sensitivity is high in highly vascularized tumors, the ability to detect tumor lesions in vivo is closely related to the size of the lesion, and is limited to lesions larger than $11 \mathrm{~mm}$ (in the case of scintigraphy) and greater than $8 \mathrm{~mm}$ (in the case of SPECT/CT). ${ }^{17,18}$

The majority of this type of tumors presents recurrence at the primary site; For this reason, the use of this technique is suggested before and after the different treatment schemes. It has even been reported that the ${ }^{201} \mathrm{Tl}$ image is more accurate than other imaging modalities, such as magnetic resonance imaging, in differentiating recurrence with post-therapeutic changes in musculoskeletal sarcomas, and it reaches a sensitivity of $100 \%$ and a specificity of $87.5 \% .^{19}$

The ability to detect malignant lesions is closely related to three factors: the normal biodistribution of ${ }^{201} \mathrm{Tl}$, the tumor vascularity and the radionuclide's route of elimination. These elements must be taken into account at the time of interpretation of scintigraphic studies. Because scintigraphy has a poor anatomic definition as it is a largely functional study, it can make it difficult to pinpoint the affected site; Hybrid equipment with SPECT/CT can solve this problem. ${ }^{19-21}$

Based on the results obtained, it is suggested that all patients undergoing thallium scintigraphy should perform a routine chest SPECT/CT if the suspicion of metastatic disease or recurrence is high, despite a negative scan, to improve the characterization and extension of the disease in a single day of study, decreasing the stress of the patient.

One of the major limitations of this paper is the dosimetry of the patients, since, in the pediatric population, this issue must be taken with particular importance. As mentioned above, for the activity employed by the patient in $\mathrm{MBq}$, the dose of radiation absorbed by the target organ (myocardium) is approximately $15 \mathrm{mGy}$, and the typical radiation doses absorbed by the critical organs (kidneys and descending colon) are $35 \mathrm{mGy}$ and $23 \mathrm{mGy}$, respectively. Also, the retrospective nature of the work prevents providing a correct long-term follow-up.

For this reason, many researchers suggest the use of other radiotracers, such as ${ }^{99 \mathrm{mTC}} \mathrm{TC}$-MIBI $(99 \mathrm{mTc}$-hexakis-2-methoxy isobutyl isonitrile), in this type of neoplasms, due to the lower dose absorbed and the similar mechanism of the tumor cell uptake, unlike the latter has a marked mitochondrial predilection. One of the most important mechanisms responsible for chemotherapy resistance is the overexpression of the multidrug-resistant gene (MDR1), which codes for the P-glycoprotein (gp-P). The expression of MDR1 is not uncommon in musculoskeletal tumors, so it is particularly important to mention that the presence of $\mathrm{gp}-\mathrm{P}$ in this type of tumors has implications for the retention of

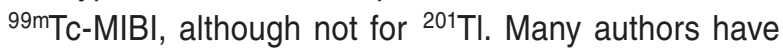
research multidrug-resistance by correlating the scinti-

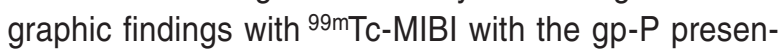
ce, demonstrating that the absence of uptake of ${ }^{99 m T C-M I B I}$ is an indicator of the presence of gp-P. This conditions an efflux of the ${ }^{99 \mathrm{~m} T C-M I B I}$ from the tumor cell, that is, a rapid washing of the radioisotope, which can lead to a high rate of false negatives. ${ }^{22-24}$.

In a sample of 30 patients with musculoskeletal tumors, Taki et al. demonstrated that tumors with no

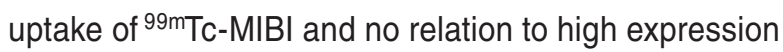
of gp-P were also associated with the absence of uptake of ${ }^{201} \mathrm{Tl}$, which is not a substrate for gp-P but is a useful marker of perfusion and viability cell phone. Therefore, scintigraphy with ${ }^{201} \mathrm{TI}$ is recommended when ${ }^{99 m} \mathrm{Tc}-\mathrm{MIBI}$ shows no uptake, to verify if the absence of uptake is due to weak blood flow or the presence of $\mathrm{gp}-\mathrm{P}$, which would lead to poor therapeutic response and poor prognosis. ${ }^{25}$

With technological advances, the use of PET/CT, and more recently PET/MRI (positron emission tomography-magnetic resonance imaging) have replaced the use of scintigraphy with ${ }^{201} \mathrm{TI}$. However, there are still many hospital centers that lack such technology. For 
this reason, the use of the scintigraphic study combined with the SPECT/CT technique can be considered as an adequate study to identify the sites of tumor viability, with a high degree of diagnostic certainty.

\section{Ethical disclosures}

Protection of human and animal subjects. The authors declare that no experiments were performed on humans or animals for this study.

Confidentiality of data. The authors declare that they have followed the protocols of their work center on the publication of patient data.

Right to privacy and informed consent. The authors have obtained the written informed consent of the patients or subjects mentioned in the article. The corresponding author is in possession of this document.

\section{Conflicts of interest}

The authors declare no conflicts of interest.

\section{Funding}

The authors of the present study did not receive any monetary or in-kind support for the preparation of the manuscript.

\section{Acknowledgments}

To all the personnel of the Nuclear Medicine Department of the Hospital Infantil de México Federico Gómez.

\section{References}

1. Pakos EE, Nearchou AD, Grimer RJ, Koumoullis HD, Abudu A, Bramer JA, et al. Prognostic factors and outcomes for osteosarcoma: an international collaboration. Eur J Cancer. 2009;45:2367-75.

2. Stiller CA, Bielack SS, Jundt G, Steliarova-Foucher E. Bone tumours in European children and adolescents, 1978-1997. Report from the Automated Childhood Cancer Information System project. Eur J Cancer. 2006;42:2124-35

3. Nadel Helen R. Thallium-201 for oncological imaging in children. Semin Nuc Med. 1993;3:243-54.
4. Ozcan Z, Burak Z, Ozcan C, Basdemir G, Ozacar T, Erdem S, et al. Is 201TI a reliable agent in tumour imaging? Nucl Med Commun. 1996; 17:805-9.

5. Otsuka H, Terezawa K, Morita N, Otomi Y, Takao S, Iwamoto S, et al. Thallium-201 chloride scintigraphy in soft tumors. J Med Invest. 2009; 56:136-41.

6. Elgazzar AH, Fernandez-Ulloa M, Silberstein EB. 201TI as a tumour-localizing agent: current status and future considerations. Nucl Med Commun. 1993;14:96-103.

7. Van der Wall H, Murray IP, Huckstep RL, Philips RL. The role of thallium scintigraphy in excluding malignancy in bone. Clin Nucl Med. 1993;18:551-57.

8. Abdel-Dayem H. 201Tl-chloride uptake ratios in differentiating benign from malignant lesions: recommendations for ratio calculations and interpretation. Nucl Med Commun. 1995;16:145-9.

9. Sumiya H, Taki J, Higuchi T, Tonami N. Nuclear imaging of bone tumors: thallium-201 scintigraphy. Semin Musculoskelet Radiol. 2001;5:177-82.

10. Howman-Giles R, Uren RF, Shaw PJ. Thallium-201 scintigraphy in pediatric soft-tissue tumors. J Nucl Med. 1995;36:1372-6.

11. Değimerci $B$, Havitçioğlu $H$, Derebek E, Uysal K, Çapa G, Çetingöz R, et al. Thallium and three-phase bone scintigraphy in the evaluation of bone and soft tissue sarcomas. TJNM. 1997;6:100-4.

12. Caluser C, Abdel-Dayem HM, Macapinlac HA, Scott A, Healey JH, Huvos $A$, et al. The value of thallium and three-phase bone scans in the evaluation of bone and soft tissue sarcomas. Eur J Nucl Med. 1994; 21:1198-205

13. Sato $O$, Kawai A, Ozaki T, Kunisada T, Danura T, Inoue $H_{.}$. Value of thallium-201 scintigraphy in bone and soft tissue tumors. J Orthop Sci. 1998;3:297-303.

14. Iguchi T, Taki J, Nakajima K, Kinuya S, Nonomura A, Tsuchiya $H$, et al. Differentiation of soft tissue haemangioma by 201TI scintigraphy. Nucl Med Commun. 2003;24:327-30.

15. Goto Y, Ihara K, Kawauchi S, Ohi R, Sasaki K, Kawai S. Clinical significance of thallium-201 scintigraphy in bone and soft tissue tumors. J Orthop Sci. 2002;7:304-12.

16. Sugawara $Y$, Kikuchi T, Kajihara M, Semba T, Ochi T, Fujii T, et al. Thallium-201 scintigraphy in bone and soft-tissue tumors: a comparison of dynamic, early and delayed scans. Ann Nucl Med. 2005;19:461-8.

17. Terui S, Terauchi T, Abe H, Fukuma H, Beppu Y, Chuman K, et al. On clinical usefulness of TI-201 scintigraphy for the management of malignant soft tissue tumors. Ann Nucl Med. 1994;8:55-64.

18. Menendez LR, Fideler BM, Mirra J. Thallium-201 scanning for the evaluation of osteosarcoma and soft-tissue sarcoma. J Bone Joint Surg Am. 1993;75:526-31.

19. Kostakoglu L, Panicek DM, Divgi CR, Botet J, Healey J, Larson SM, et al. Correlation of the findings of thallium-201 chloride scans with those of other imaging modalities and histology following therapy in patients with bone and soft tissue sarcomas. Eur J Nucl Med. 1995;22:1232-7.

20. Khalil MM, Tremoleda JL, Bayomy TB, Gsell W. Molecular SPECT imaging: an overview. Int J Mol Imag. 2011:1-15.

21. Nishiyama $Y$, Yamamoto $Y$, Toyama $Y$, Satoh K, Ohkawa M, Tanabe M. Diagnostic value of TI-201 and three-phase bone scintigraphy for bone and soft-tissue tumors. Clin Nucl Med. 2000;25:200-5.

22. Rao VV, Chiu ML, Kronauge JF, Piwnica-Worms D. Expression of recombinant human multidrug resistance P-glycoprotein in insect cells confers decreased accumulation of technetium-99m-sestamibi. J Nuc Med. 1994;35:510-5.

23. Cordobes MD, Starzec A, Delmon-Moingeon L, Blanchot C, Kouyoumdjian JC, Prévost G, et al. Technetium-99m-sestamibi uptake by human benign and malignant breast tumor cells: correlation with MDR gene expression. J Nuc Med. 1996;37:286-9.

24. Luker GD, Fracasso PM, Dobkin J, Piwnica-Worms D. Modulation of the multidrug resistance P-glycoprotein: detection with Technetium-99m-sestamibi in vivo. J Nuc Med 1997;38:369-72.

25. Taki J, Sumiya H, Asada N, Ueda Y, Tsuchida H, Tonami N. Assessment of P-glycoprotein in patients with malignant bone and soft-tissue tumors using technetium-99m-MIBI scintigraphy. J Nuc Med. 1998;39:1179-84. 